\title{
Defining the "Essence of the Business": An Analysis of Title VII's Privacy BFOQ after Johnson Controls
}

\author{
Jillian B. Berman $\dagger$
}

Consider the following scenario: David, a male nurse, responds to a job advertisement for a nurse in the labor unit of a hospital. When he submits his application, David is told that the position is open only to female nurses, in order to protect the privacy interests of the parturient women.

Title VII of the Civil Rights Act prohibits employers from discriminating "against any individual with respect to his compensation, terms, conditions, or privileges of employment, because of such individual's ... sex." Intentional discrimination based on sex is permissible, however, for jobs in which sex is a "bona fide occupational qualification ('BFOQ') reasonably necessary to the normal operation of that particular business or enterprise." The BFOQ is an affirmative defense that is available to employers who can show that "the essence of [their] business operation would be undermined by not hiring members of one sex exclusively.",

This Comment focuses specifically on the BFOQ commonly known as the "privacy BFOQ" as it relates to the health care industry." The privacy BFOQ applies to sex-based employment policies that employers claim are necessary to protect the privacy interests of their patients, clients, or customers. For example, one court has held that a hospital may refuse to hire men to work as nurses in the labor and de-

\footnotetext{
$\dagger$ B.S. 1997, Cornell University; J.D. Candidate 2000, The University of Chicago.

1 Title VII of the Civil Rights Act of 1964, Pub L No 88-532 $\$ \S 701-06,78$ Stat 241, 255 (1964), codified as amended at 42 USC \$ 2000e-2(a)(1) (1994).

2 Section 703(e)(1) of Title VII, 42 USC $\$ 2000 \mathrm{e}-2(\mathrm{e})(1)$. The employer bears the burden of proof for this affirmative defense. See Diaz v Pan American World Airways, Inc, 442 F2d 385, 388-89 (5th Cir 1971).

3 Dothard $v$ Rawlinson, 433 US 321, 323 (1977), quoting Diaz, 442 F2d at 388. There are various justifications for the BFOQ exception to Title VII. See EEOC Guideline on Discrimination Because of Sex, 29 CFR $\$ 1604.2$ (a)(2) (1984) (ensuring authentic performances by actors and actresses); Torres $v$ Wisconsin Department of Health and Social Services, 859 F2d 1523, 1530 (7th Cir 1988) (furthering the rehabilitation of female prisoners); Chambers v Omaha Girls Club, Inc, 834 F2d 697,702 (8th Cir 1987) (preserving the role model status of a Girls Club staff member); Levin v Delta Air Lines, Inc, 730 F2d 994, 997 (5th Cir 1984) (protecting the physical safety and security of airline passengers). This Comment focuses on the BFOQ justified as protecting the privacy of third parties. See notes 6-11.

4 It is also referred to as the "BFOQ based on privacy."
} 
livery units without violating Title VII, because female patients would not feel comfortable with male nurses.

The patients' privacy interests do not relate to an employee's physical ability to do the job. ${ }^{6}$ Courts have accepted a privacy BFOQ most frequently where the job in question requires the employee to view a patient's naked body. Existing law permits sex-based employment policies with respect to nurses,' nurses' aides, janitors, 'child care specialists at psychiatric hospitals, ${ }^{10}$ and prison guards ${ }^{11}$ because these jobs sometimes require employees to view the naked bodies of patients or inmates. ${ }^{12}$

Even though Congress provided the statutory BFOQ defense in order to permit some sex-based employment policies, the Supreme Court has stated that it was "meant to be an extremely narrow exception to the general prohibition of discrimination." ${ }^{13}$ The Court recently reaffirmed the limited scope of the exception in International Union, $U A W v$ Johnson Controls, Inc. ${ }^{14}$ In practice, however, the privacy BFOQ has been interpreted broadly in the health care industry. The burden for establishing this BFOQ has not been difficult for employers to satisfy, and courts have often permitted the defense where the Equal Employment Opportunity Commission ("EEOC") has urged otherwise.

5 See Backus v Baptist Medical Center, 510 F Supp 1191, 1194-95 (E D Ark 1981), vacated on other grounds, 671 F2d 1100, 1102-03 (8th Cir 1982).

6 See Fesel v Masonic Home of Delaware, Inc, 447 F Supp 1346, 1354 (D Del 1978) (citations omitted) (finding that female sex was a BFOQ for the position of nurse's aide at a residential retirement home, even though male aides were physically capable of performing the job duties, based on evidence that female guests objected to treatment by male nurses), affd, 591 F2d 1334 (3d Cir 1979).

7 See Backus, 510 F Supp at 1194-95.

8 See Jones v Hinds General Hospital, 666 F Supp 933, 936-37 (S D Miss 1987) (holding that the hospital established that male sex was a BFOQ for hospital orderlies in order to preserve the privacy interests of male patients).

9 See Brooks v ACF Industries, Inc, 537 F Supp 1122, 1133 (S D W Va 1982) (holding that male sex was a BFOQ for employment as a janitor where janitorial duties included cleaning men's bathhouses).

10 See Healey y Southwood Psychiatric Hospital, 78 F3d 128, 133-34 (3d Cir 1996) (permitting a privacy-based BFOQ for child care specialists at a psychiatric hospital where the specialist's duties include accompanying children to the bathroom and occasionally bathing them).

11 See Robino v Iranon, 145 F3d 1109, 1110-11 (9th Cir 1998) (holding that female sex constituted a BFOQ for six of forty-one corrections officer positions at a women's prison).

12 For example, prison guards sometimes must conduct body cavity searches of inmates, and some employers argue that guards who perform this duty must be the same sex as the prisoner. See Torres, 859 F2d at 1525.

13 Dothard, 433 US at 334. See also 29 CFR $\$ 1604.2$ (a) (describing the EEOC's belief that exceptions "should be interpreted narrowly").

14499 US 187, 201 (1991) (holding that male sex was not a BFOQ for jobs involving exposure to lead at a battery manufacturing plant where protecting potential fetuses from lead exposure did not constitute the essence of the business).

15 See discussion in Part I.C.2. 
The privacy $B F O Q$, which currently may prevent male nurses from obtaining jobs because of their sex, may also result in the denial of salaried jobs to male physicians, particularly obstetricians and gynecologists ("OB-GYNs"). If so, these physicians, an increasing number of whom are salaried employees protected by Title VII, may begin to file sex discrimination lawsuits."

This Comment argues that the current test courts use to determine whether sex is a privacy BFOQ in the health care industry is too broad and therefore is inconsistent with the Supreme Court's interpretation of Title VII in Johnson Controls. In addition, while guidelines promulgated by the EEOC do not have the binding force of precedent, and decisions that do not conform to EEOC guidelines are not necessarily invalid, courts have permitted the privacy BFOQ

16 The application of the privacy BFOQ to obstetricians and gynecologists is foreseeable for three reasons: (1) The influx of "employee" doctors protected under Title VII. See note 17. (2) The increasing percentage of obstetricians and gynecologists who are female. See Leigh Page, Will Women Become the New OB-GYN Majority?, 34 Am Med News No 46, 15 (Dec 9, 1991) (reporting that while women were still a minority among OB-GYN residents overall, they make up 54 percent of first-year residents). See also Phil Galewitz, Women Doctors: How Critical is Gender When Ob/Gyn Care is the Issue?, Harrisburg Patriot and Evening News G1 (Mar 28, 1993) (reporting that by the turn of the century, there will be 40,000 physicians in the OB-GYN specialty, 28 percent of whom will be women). (3) The increasing preference by women for female doctors, and specifically for female obstetricians and gynecologists. For studies indicating that women increasingly prefer female obstetricians and gynecologists, see Genevieve Buck, Mirror Images: More Patients Are Looking For Doctors Who Reflect Their Concerns, Chi Trib C1 (June 12, 1994); and American Health Line, 6 Am Political Network No 9 (June 24, 1999). The growing preference for female OB-GYNs is likely to be bolstered by the fact that some male doctors actively urge women to seek obstetric and gynecological care from female doctors. See John M. Smith, Women and Doctors: A Physician's Explosive Account of Women's Medical Treatment-and Mistreatment-in America Today and What You Can Do About It 25-29 (Atlantic Monthly 1992). Smith, a Colorado physician, argues that men should have no role in managing pregnancy and childbirth or treating the female sexual organs.

17 The protection afforded to physicians under Title VII is relatively new. Traditionally, doctors have not been covered by Title VII because they have not been employees, but have either owned their own practices, formed partnerships with other doctors, or contracted out their services to hospitals. See Erin E. Flaharty, Dazed \& Confused-The Uncertain State of the Law Regarding Whether Hospitals' Denial of Staff Privileges to Physicians May Be Challenged under Title VII or the ADA, 34 Ariz Atty 24, 25 (Apr 1998). Employment relationships in the health care industry have changed as health care services have shifted to managed care. Managed care organizations, particularly HMOs, have increased dramatically in the United States as a result of skyrocketing costs of medical care. HMO enrollees doubled from 1981 to 1985 . By 1988, enrollment was approximately thirty-three million; by 1998 it was eighty million. See Walter A.Zelman and Robert A. Berensen, The Managed Care Blues and How to Cure Them 53, 55 (Georgetown 1998) (citation omitted). This shift has resulted in many salaried physicians who are considered to be employees rather than independent contractors. See Note, The Impact of Managed Care on Doctors Who Serve Poor and Minority Patients, 108 Harv L Rev 1625,1631 (1995) (citation omitted). Approximately one-half of the nation's physicians are in salaried positions in hospitals and HMOs, while the other half are independent contractors. See Nation in Brief, The Atlanta Const A10 (Mar 2,1999). An estimated 80 percent of medical school graduates over the last five years have taken salaried jobs and are employees. See Glenn Burkins, Health-Care Union to Organize Doctors in Drive Aimed at Industry Power Shift, Wall St J A6 (Mar 2, 1999). These "employee" doctors are protected under Title VII. 42 USC $\$ 2000 \mathrm{e}-2(\mathrm{a})(1)$. 
where it is based on stereotyped characterizations of the sexes, which are prohibited under EEOC guidelines.

Part I of this Comment focuses on the case law dealing with the privacy BFOQ and argues that Johnson Controls restricts the permissibility of the privacy BFOQ. Because of this, courts should apply a higher burden to employers seeking to establish a privacy BFOQ. This Part also shows that the privacy BFOQ case law is inconsistent with the EEOC's longstanding interpretation of Title VII.

Part II sets forth a proposal to aid courts in narrowing the application of the privacy BFOQ. Specifically, courts should apply two rules when determining if sex is a privacy BFOQ. First, sex is not a privacy BFOQ where an employer permits employees of one sex (for example, female nurses) to treat patients of the opposite sex (male patients) but does not permit employees of the other sex (male nurses) to treat patients of the opposite sex (female patients). Second, where an employer permits physicians of both sexes to intimately treat patients of the opposite sex, but does not permit nurses of both sexes to intimately treat patients of the opposite sex, a privacy BFOQ is not available.

These rules will aid courts in narrowing the privacy BFOQ by getting at whether privacy is, in addition to health care, the essence of a particular business. In addition to providing a way for courts to narrow the privacy BFOQ consistent with Johnson Controls, these rules gain legitimacy because they conform to the EEOC guidelines and ensure that the privacy $\mathrm{BFOQ}$ does not perpetuate sex stereotypes. Before setting forth the details of this proposal, Part II.A observes that limiting the privacy BFOQ may infringe upon patients' privacy interests and will force them to adapt to new health care conditions. Such a change in notions of privacy is not unprecedented. To support the viability of a proposal that depends upon, or results in, the mutability of privacy interests, this Part presents historical evidence to illustrate that such privacy interests are mutable. While there may be a period of adjustment, this evidence shows that notions of privacy can and do change.

\section{AN INTERPRETATION OF THE PRIVACY BASED BFOQ}

Under current case law, sex constitutes a BFOQ based on privacy in a variety of situations. ${ }^{18}$ Courts have permitted hospitals, nursing homes, home health care agencies, and other employers such as cleaning agencies to maintain discriminatory hiring policies for nurses,

18 This is in spite of the fact that some courts have held that the BFOQ defense was intended to be very narrow. See text accompanying notes $6-12$, which describes the privacy BFOQ. 
nurses' aides, and cleaning staff based on the privacy interests of third parties."

Typically, courts apply the "essence of the business" test to determine whether sex is a BFOQ for a particular occupation. ${ }^{20}$ When courts have interpreted this test in cases involving the privacy BFOQ, they have generally required an employer to show two things. First, the employer must show that there is a factual basis for believing that hiring one sex would undermine the essence of the employer's business. Second, the employer must show that no reasonable alternative or accommodation exists that could avoid or mitigate the conflict between equal employment opportunities and privacy interests. ${ }^{21}$

Courts have interpreted the first prong loosely in privacy BFOQ cases and have often found it satisfied if the employer shows that the clients or guests of a particular business would not consent to service by a member of the opposite sex and that the clients or guests would stop patronizing the business if members of the opposite sex were allowed to perform the service. ${ }^{2}$ For example, evidence presented by one employer to establish a privacy BFOQ included speculative testimony by a doctor that one-half of her patients would object to treatment by a male nurse, and more than one-half of their husbands would object. ${ }^{23}$ The doctor also testified that she would object to treatment by a male nurse. ${ }^{24}$ This prong can be satisfied even where both sexes are physically capable of performing all necessary job duties. The second prong of this test serves to ensure that no feasible reconciliation can be achieved between the general nondiscrimination principle of Title VII and the privacy rights of customers, clients, or patients. ${ }^{26}$ After describing the central cases involving the privacy BFOQ,

19 See notes 6-11.

20 This test was developed in Diaz v Pan American World Airways, Inc, 442 F2d 385, 388 (5th Cir 1971), and was affirmed by the Supreme Court in Dothard v Rawlinson, 433 US 321, 333 (1977), and Johnson Controls, 499 US at 203.

21 See Hardin $v$ Stynchcomb, 691 F2d 1364, 1370-71 (11th Cir 1982) (describing an employer's obligation to eliminate the clash between privacy and non-discrimination by reassignment if possible); Gunther v Iowa State Men's Reformatory, 612 F2d 1079, 1086 (8th Cir 1980) (emphasizing that the employer must show a factual basis and the impracticality of reassigning jobs); Fesel v Masonic Home of Delaware, Inc, 447 F Supp 1346, 1351 (D Del 1978), affd, 591 F2d 1334 (3d Cir 1979) (considering whether selective job assignment would remedy privacy concerns).

22 See EEOC v Mercy Health Center, 29 FEP Cases (BNA) 159, 162 (W D Okla 1982) (describing customer preferences as particularly important in the privacy context); Fesel, 447 F Supp at $1352-53$ (giving the guests' privacy interests great weight).

23 See Backus v Baptist Medical Center, 510 F Supp 1191, 1196 (E D Ark 1981).

24 Id.

25 See Fesel, 447 F Supp at 1350.

26 Consider id at 1351 (noting that courts will tolerate only a "minimal" infringement on customers' privacy interests). 
this Part will explain why the courts' application of the BFOQ in those cases seems inconsistent with recent Supreme Court precedent.

\section{A. Case Law Surrounding the Privacy BFOQ}

Four cases demonstrate that courts will allow sex discriminatory policies in hiring nurses and nurses' aides: Fesel v Masonic Home of Delaware, Inc, Jones $v$ Hinds General Hospital, Backus $v$ Baptist Medical Center, and EEOC v Mercy Health Center. ${ }^{30}$ Fesel and Jones both involved residential retirement homes that refused to hire nursing aides of one sex to treat patients of the opposite sex. In Fesel, the retirement home would not hire male aides because they would have to perform intimate duties such as dressing and bathing patients, inserting catheters, and changing geriatric pads for female patients. The nursing home believed this would violate the privacy interests of female residents. ${ }^{31}$ In Jones, the nursing home laid off eleven female nursing aides, including the plaintiff, while retaining several male orderlies with less seniority. ${ }^{32}$ The orderlies performed essentially the same duties as the nursing assistants, including bathing patients and administering enemas.

Both the Jones court and the Fesel court found that the defendants had a factual basis for believing that hiring nurses of both sexes would undermine the essence of their businesses. ${ }^{34}$ Masonic Home, the defendant in Fesel, showed this through the testimony of several witnesses, who opined that women would object to intimate touching by males. Masonic also presented an affidavit signed by nine of the twenty-two female residents of Masonic Home, noting that they objected to the employment of male nurses and might leave the nursing home if this occurred. ${ }^{35}$ The defendant in Jones met its burden of establishing that male sex was a BFOQ for orderlies by presenting testimony from a hospital administrator, a urologist employed at the hospital, and nurses. These testimonies indicated that some male patients objected to being exposed to female nursing assistants.

27447 F Supp 1346 (D Del 1978), affd, 591 F2d 1334 (3d Cir 1979).

28 666 F Supp 933 (S D Miss 1987).

29510 F Supp 1191 (E D Ark 1981), vacated on other grounds, 671 F2d 1100, 1102-03 (8th Cir 1982).

3029 FEP Cases (BNA) 159 (W D Okla 1982) (finding that female gender is a BFOQ for the position of staff nurse in the labor and delivery area of a health care facility, where duties of these nurses include intimate ones).

31 See Fesel, 447 F Supp at 1348-52.

32 See Jones, 666 F Supp at 934.

33 See id.

34 See id at 936; Fesel, 447 F Supp at 1352-53.

35 See Fesel, 447 F Supp at 1352-53. .

36 See Jones, 666 F Supp at 936. 
With regard to the second prong of the "essence of the business" test, both the Fesel court and the Jones court found that there were no reasonable alternative practices or accommodations with a less discriminatory impact. ${ }^{37}$ In Jones, at the time of the layoff, the defendant had four full-time orderlies and three who were used on an as-needed basis. The full-time orderlies worked seven twelve-hour shifts in fourteen days, and there was one available in the hospital at all times to help out where needed. ${ }^{38}$ The court determined that this schedule required a minimum of four full-time male orderlies. ${ }^{39}$ At the time the plaintiffs were laid off, the hospital had two male nursing assistants, and two or three male nurses. However, the male nurses were assigned to specific units, and it was "impractical" for them to be available throughout the hospital. Thus, the court concluded that the only reasonable way the defendant could accommodate privacy interests of male patients was to retain the male orderlies.

Backus and Mercy Health both involved medical facilities that hired only female nurses to work in the labor and delivery units. Both courts found that these policies were permissible because female sex was a BFOQ for nurses who worked in the labor and delivery units of the health center. In Backus, Baptist Medical Center ("Baptist") refused to permit males to work in the OB-GYN unit of the hospital "because of the concern of our female patients for privacy and personal dignity which make[s] it impossible for a male employee to perform the duties of this position effectively." quired, in addition to many non-intimate duties, substantial contact with the mother's genitalia. The center in Mercy Health contended that female sex was a BFOQ for these positions based upon "its belief in the patient's right to privacy and upon the medical necessity of minimizing the tension, fear, and stress which accompany the labor and delivery experience." ${ }^{, 3}$

The court permitted the privacy BFOQ in Backus. It found that the evidence presented by the defendant, which consisted primarily of testimony by hospital staff, established that Baptist had a factual basis for believing that female patients would object to intimate touching by male nurses, and that male nurse care would undermine the hospital's business. ${ }^{4}$ Similarly, the Mercy Health court agreed that, based on

\footnotetext{
37 See id at 936-37; Fesel, 447 F Supp at 1353.

38 See Jones, 666 F Supp at 936-37.

9 See id at 937.

See id.

Backus, 510 F Supp at 1192.

See id at 1193.

Mercy Health, 29 FEP Cases (BNA) at 160-61.

See Backus, 510 F Supp at 1195-96.
} 
evidence that 60 to 70 percent of the mothers and a larger percentage of fathers objected to the use of male nurses in the labor unit, there was "a factual basis for determining that the employment of male nurses in the labor and delivery area would cause medically undesired tension." ${ }^{45}$ However, Mercy Health had presented no additional evidence that the presence of male nurses would undermine the essence of the hospital's business.

In addition, the courts in Backus and Mercy Health both found that no reasonable accommodation could be made to allow the employment of male nurses. The courts noted that "insurmountable problems would occur" if the defendant had to permit male nurses to work in the labor and delivery unit but was forced to reassign intimate duties to female nurses. ${ }^{46}$ Also, because both hospitals had a "chaperon policy," where a chaperon was normally present whenever a patient's genital area was examined by someone of the opposite sex, accommodations were even more difficult because " $a$ job that required only one nurse will now require two, and this will cause a strain on the nursing staff, increase the hospital's costs, and reduce the hospital's efficiency.",

\section{B. The Supreme Court's Construction of the BFOQ Defense}

A recent Supreme Court case, International Union, UAW v Johnson Controls, Inc, casts doubt on the future of the privacy BFOQ. In Johnson Controls, the Court confirmed that courts should use the "essence of the business" test in determining whether sex is a BFOQ." However, the Court insisted on construing the "essence of the business" test narrowly, which suggests that courts should develop a new approach to determine whether sex is a privacy BFOQ.

Johnson Controls dealt with a BFOQ based on safety concerns rather than privacy. The plaintiffs, a group of female employees, challenged Johnson Controls' policy, of excluding fertile women from positions that involved exposure to lead. Johnson Controls, the employer, defended its action by arguing that male sex was a BFOQ for these positions because lead exposure can cause health problems, including harm to fetuses.

45 Mercy Health, 29 FEP Cases (BNA) at 161, 163. Some doctors also objected to the employment of male nurses in the labor unit. Id.

46 Backus, 510 F Supp at 1197.

47 See id; Mercy Health, 29 FEP Cases (BNA) at 161.

48 Backus, 510 F Supp at 1198. See also Mercy Health, 29 FEP Cases (BNA) at 161, 163.

49499 US 187 (1991).

50 See id at 203.

51 See id at 191-96. 
The Supreme Court began its analysis of the BFOQ exception by noting that it was narrow.

The BFOQ defense is written narrowly, and this Court has read it narrowly. See, e.g., Dothard v. Rawlinson, 433 U.S. 321, 332-337 (1977); Trans World Airlines, Inc. v. Thurston, 469 U.S. 111, 122125 (1985). . . . Our emphasis on the restrictive scope of the $\mathrm{BFOQ}$ is grounded on both the language and the legislative history of $\S 703$.

The wording of the BFOQ defense contains several terms of restriction that indicate that the exception reaches only special situations. The statute thus limits the situations in which discrimination is permissible to "certain instances" where sex discrimination is "reasonably necessary" to the "normal operation" of the "particular" business.

Next, the Court determined that the term "occupational" in the BFOQ provision meant that the exception could not be invoked unless "job-related skills and aptitudes" were at issue. ${ }^{53}$ Finally, the Court stressed that in order to qualify as a BFOQ, "a job qualification must relate to the 'essence' ... or to the 'central mission of the employer's business." "'st The Court stated that this was the only logical interpretation of the "bona fide occupational qualification." "By modifying 'qualification' with 'occupational,' Congress narrowed the term to qualifications that affect an employee's ability to do the job.",

The Court then stated that "[o]ur case law, therefore, makes clear that the safety exception is limited to instances in which sex or pregnancy actually interferes with the employee's ability to perform the job." ${ }^{* 6}$ The Court determined that this approach was consistent with the language of the $\mathrm{BFOQ}$ provision that permissible distinctions based on sex must relate to the ability to perform the essential duties of the job. Thus, the Court concluded that sex did not constitute a BFOQ at Johnson Controls because being female in no way interfered with an employee's ability to make batteries, which was the essence of Johnson Controls' business." The Court emphatically rejected the employer's attempt to broadly construe the "essence" of its business": "It

52 Id at 201.

53 Id.

54 Id at 203, citing Dothard $v$ Rawlinson, 433 US 321, 333 (1977), and Western Air Lines, Inc $v$ Criswell, 472 US 400, 413 (1985) (emphasizing that a job qualification cannot be merely peripheral).

55 Johnson Controls, 499 US at 201.

56 Id at 204.

57 Id at 204-06.

58 The Court rejected the broad interpretation of the essence of the employer's business 
is word play to say that 'the job' at Johnson [Controls] is to make batteries without risk to fetuses in the same way 'the job' at Western Air Lines is to fly planes without crashing.",

Justice White pointed out in his concurrence in Johnson Controls that the majority's interpretation of the BFOQ would disallow use of privacy as a basis for a BFOQ:

The Court's interpretation of the BFOQ standard also would seem to preclude considerations of privacy as a basis for sexbased discrimination, since those considerations do not relate directly to an employee's physical ability to perform the duties of the job.

The majority responded to Justice White briefly and without addressing his concerns, as privacy interests were not at issue in Johnson Controls. The Court stated that while it had never addressed privacybased sex discrimination, nothing in its discussion of the "essence of the business" test suggested that sex could not be a BFOQ when privacy interests are implicated. ${ }^{61}$ Yet the Court did not explain how privacy interests could possibly constitute a BFOQ if the "essence" of a particular business must be defined narrowly and includes only that which is central to its mission.

Two conceivable interpretations follow from Johnson Controls. The first is that the majority's interpretation of the "essence of the business" eviscerates the privacy BFOQ, because the essence of any

that some circuit courts had adopted. See Torres $v$ Wisconsin Department of Health and Social Services, 859 F2d 1523, 1529-30 (7th Cir 1988), where the essence of the business of a women's prison included not just prison security, but also a rehabilitative environment free of any male presence. In the Seventh Circuit opinion in Johnson Controls, the employer's "essence of the business" was described as not just making batteries, but making batteries without adverse fetal safety consequences. International Union, UAW v Johnson Controls, Inc, 886 F2d 871, 896 (7th Cir 1989).

59 Johnson Controls, 499 US at 207, quoting Johnson Controls, 886 F2d at 913 (Easterbrook dissenting). This narrow construction of the essence of an employer's business was consistent with earlier cases. For example, in the famous case of Wilson $v$ Southwest Airlines Co, $517 \mathrm{~F}$ Supp 292 (N D Tex 1981), Wilson challenged Southwest's policy of hiring only female employees for customer contact positions such as flight attendants and ticket agents. Southwest, calling itself the "love airline" personified by feminine youth and vitality, asserted that its female-only personnel policy went to the essence of its unique, corporate persona. Id at 295-300. Southwest argued that transporting passengers with "love" was the essence of its business, and that the female-only hiring policy was crucial to its success. Id at 303-04. The court rejected Southwest's argument, and stated that the business essence requirement must be interpreted narrowly and specifically. In this regard, the court stated, "'Love' is the manner of job performance, not the job performed." Id at 302. Thus, the court found that the essence of the business element of the BFOQ test is satisfied only if a nondiscriminatory policy would preclude the successful performance of the employer's primary business mission, which in this instance was transporting passengers. Id.

60 Johnson Controls, 499 US at $220 \mathrm{n} 8$ (White concurring).

61 See id at 206 n 4 (majority). 
health care facility is to provide health care, irrespective of causing tension or embarrassment. Or instead, Johnson Controls can be interpreted as requiring that courts interpret the privacy $\mathrm{BFOQ}$ more narrowly, and permit it only where employers establish that protecting patient privacy is central to the business - this may be shown, for example, where an employer establishes that absent the BFOQ, he may not be able to provide health care at all because he has lost all of his customers.

\section{Problems with the Privacy BFOQ}

1. The impact of Johnson Controls on the privacy BFOQ.

The case law surrounding the privacy BFOQ is inconsistent with the Court's narrow understanding of BFOQs in Johnson Controls. ${ }^{62}$ While Justice White was correct to point out that the Court's opinion in Johnson Controls threatens the future of the privacy BFOQ, the privacy BFOQ does survive. Johnson Controls requires, however, that courts determine the essence of a particular business, and that the essence must be defined narrowly. A health care provider must establish that patient privacy goes to the essence of that particular business in order for sex to constitute a privacy BFOQ.

Post-Johnson Controls defendants presenting claims similar to those asserted in Fesel, Backus, Jones, and Mercy Health should not prevail on a similar evidentiary showing. Evidence such as that presented in Fesel, Backus, Jones, and Mercy Health, indicating an employer's belief that some patients might not consent to treatment by a member of the opposite sex, does not prove that the essence of a business is to do anything other than provide health care; nor does it establish that the employer will not be able to provide health care at all absent the BFOQ because it will have no patients. This is not sufficient after Johnson Controls. Just as the Supreme Court rejected the defendant's argument that the essence of its business was to make batteries without risk to fetuses, and found instead that the essence of the business was solely to make batteries, post-Johnson Controls courts should find that the essence of the businesses in cases like Backus, Jones, Mercy Health, and Fesel is to provide health care. Courts have no basis for finding that a particular business's essence is more than

62 The four central privacy BFOQ cases concerning the health care industry are Fesel, 447 F Supp 1346; Jones, 666 F Supp 933; Backus, 510 F Supp 1191; Mercy Health Center, 29 FEP Cases (BNA) 159. These cases are somewhat dated, and there are no recent privacy BFOQ cases that are specific to the health care industry. Lack of litigation does not mean that few employers are implementing sex discriminatory policies, however, and given that the courts in Fesel, Backus, and Mercy Health were quick to side with the employer and permit a same-sex privacy BFOQ, it is likely that some employees who are hurt by sex discriminatory employment policies decide not to sue. 
that based upon evidence that, at the worst, some clients may leave if treated by members of the opposite sex. Unfortunately, even where post-Johnson Controls courts analyzing the privacy BFOQ have focused on whether the "essence" or "central mission" of a particular business is to protect patients' or customers' privacy, they have not always interpreted the "essence" narrowly."

\section{The clash between the EEOC and the privacy BFOQ.}

When Congress passed Title VII in 1964, it charged the EEOC with administering, interpreting, implementing, and enforcing it. ${ }^{64}$ In response, the EEOC issued guidelines in 1965 in order to aid courts. The EEOC does not oppose the BFOQ where "it is necessary for the purpose of authenticity or genuineness ... e.g., an actor or actress." However, the guidelines forbid discrimination based on "assumptions of the comparative employment characteristics of women," "stereotyped characterizations of the sexes," and labels designating jobs as "[m]en's jobs" and "[w]omen's jobs." Additionally, the guidelines state explicitly that the BFOQ is not permitted where it is based on certain kinds of customer preferences. ${ }^{\circ 8}$ For example, airlines are not permitted to hire only female flight attendants even if they believe their customers "prefer" attractive stewardesses."

63 For example, in EEOC v Sedita, 816 F Supp 1291 (N D Ill 1993), the district court vacated a partial summary judgment in favor of the EEOC. The EEOC had brought a Title VII action against a women's health club to enjoin it from continuing its gender-based hiring policies. Sedita, the president and sole shareholder of fifteen exclusively female health clubs named Women's Workout World ("WWW"), implemented a female-only employment policy for all positions because these jobs involved substantial intimate physical contact with the members, including exposure to nudity in showers, locker rooms, and exercise rooms. The defendant argued that hiring men would violate club members' privacy interests. Id at 1293 . In determining whether female sex was a BFOQ based on privacy, the court looked to Mercy Health, Backus, and Fesel, and then the court asked whether protecting privacy was the essence of the employer's business. Id at 1296. It stated, "Although the EEOC makes a valid argument that the essence of WWW is providing exercise classes, defendant's evidence allows a reasonable inference that the 'essence' of WWW can be more broadly construed as providing personal and individual service to an exclusively female clientele." Id (emphasis added). In broadly construing the essence of WWW's business, the court directly contradicted the approach Johnson Controls employed.

64 See 42 USC $\$ 2000 \mathrm{e}-4(\mathrm{~g})$ (1994). See also Wilson v Southwest Airlines, 517 F Supp 292, 298-99 (1981) (noting that the EEOC has historically interpreted the BFOQ defense narrowly); Mercy Health, 29 FEP Cases (BNA) at 162 (recognizing that the EEOC's interpretation of $B F O Q$ should be given substantial weight but interpreting the BFOQ broadly).

65 See 29 CFR $\$ 1604.2$ (1965).

6629 CFR $\& 1604.2(a)(2)$.

6729 CFR $\$ 1604.2(a)(1)$.

68 See 29 CFR $\& 1604.2$ (a)(1)(iii) (stating that the EEOC will not find a BFOQ exception to satisfy the "preferences of coworkers, the employer, clients or customers").

69 See Wilson, 517 F Supp at 298 (citing EEOC guidelines and refusing to allow customer preferences to establish a $B F O Q)$. 
The EEOC has issued guidelines interpreting various provisions of Title VII, and while some have received deference, others have not. ${ }^{70}$ In General Electric Co $v$ Gilbert, ${ }^{n}$ the Supreme Court set forth a test for determining how much deference courts should give to particular guidelines promulgated by the EEOC. Quoting an earlier case, the Court wrote:

We consider that the rulings, interpretations and opinions of the [EEOC] under this Act, while not controlling upon the courts by reason of their authority, do constitute a body of experience and informed judgment to which courts and litigants may properly resort for guidance. The weight of such a judgment in a particular case will depend upon the thoroughness evident in its consideration, the validity of its reasoning, its consistency with earlier and later pronouncements, and all those factors which give it power to persuade, if lacking power to control. ${ }^{n}$

In applying this test in Gilbert, the Court found that the decisive factors as to whether a court should defer to a particular EEOC guideline were: (1) whether the particular EEOC guideline at issue was a contemporaneous interpretation of Title VII or was promulgated significantly after Title VII was enacted; and (2) whether the guideline was consistent with, or instead directly contradicted, an earlier position taken by the EEOC at a date closer to the date of enactment. $^{\text {"3. }}$

Application of these factors led the Gilbert court to hold that the guideline at issue did not deserve deference because it had not been issued contemporaneously to Title VII and had contradicted a previous position taken by the EEOC. ${ }^{74}$ However, these factors lead to the opposite result with respect to the EEOC guidelines on the BFOQ and any proposal to narrow the construction of the privacy BFOQ

70 The EEOC's published position is that a BFOQ cannot be based on customer preferences and stereotyped characterizations of the sexes. The EEOC did, in one Commission decision, state that an employer can establish a BFOQ based on privacy if he proves that he had a factual basis for believing that hiring any members of one sex would directly undermine the essence of the business, and that he could not assign job responsibilities selectively in such a way that there would be minimal clash between the interests of the customers and the nondiscrimination principle of Title VII. See EEOC Dec No 82-4, 1982 WL 21177, *2 (1982). The Commission held that this showing had not been satisfied, however, so no privacy BFOQ was permitted. Thus, the Commission did not need to consider whether the BFOQ would have been based on customer preferences or stereotyped characterizations of the sexes; even if it had, the Commission could have concluded that the BFOQ was not based on stereotypes or customer preferences. Thus, this decision is not inconsistent with the EEOC's published position regarding the BFOQ.

$71 \quad 429$ US 125 (1976).

72 Id at 141-42, quoting Skidmore v Swift \& Co, 323 US 134, 140 (1944).

73 See Gilbert, 429 US at 142.

74 See id at $142-43$. 
should conform to this guideline. Unlike the guideline in Gilbert, the EEOC's guideline regarding BFOQs was promulgated in 1965, almost simultaneously with Title VII. Furthermore, the EEOC's position with respect to the scope of the $\mathrm{BFOQ}$ has been consistent for thirty-five years. ${ }^{75}$

While courts interpreting the BFOQ generally have paid deference to these guidelines, ${ }^{76}$ courts applying the privacy BFOQ have not. As Part II.C explains in greater detail, courts permit the privacy BFOQ where it is based on "stereotyped characterizations of the sexes," and permit discrimination based on labels of "men's jobs" and "women's jobs." This is evident where courts permit sexdiscriminatory policies with respect to one sex and not the other. It is possible, however, for employers to cater to their customers' privacy interests without violating the EEOC guidelines-that is, without perpetuating stereotyped characterizations of the sexes. The next Part will explain how.

\section{A PROPOSAL FOR COURTS}

This Part sets forth a proposal that, if adopted by courts, would narrow the application of the privacy BFOQ in a manner that is both consistent with Johnson Controls and is appropriately deferential to the EEOC guidelines. The current practice of loosely applying the essence of the business test is questionable after Johnson Controls. Instead, courts should apply two rules that will rein in the privacy BFOQ.

The first rule is that if an employer has an asymmetric sexdiscriminatory policy - one that applies to one sex but not the otherthen sex is not a privacy BFOQ. This rule follows from the conclusion that asymmetric sex-discrimination is impermissibly based upon sex stereotypes and customer preferences. The second rule is that if an employer has a sex-discriminatory policy with respect to nurses or nursing aides but not to doctors, then sex is not a privacy BFOQ. This rule follows from the conclusion that such a policy is impermissibly based upon sex stereotypes.

75 See Wilson, 517 F Supp at 298 (stating that the EEOC has "steadfastly adhered to its position that customer preference gives rise to a bona fide occupational qualification for sex ... only ' $[w]$ here it is necessary for the purpose of authenticity or genuineness"'), quoting 29 CFR $\$ 1604.2(\mathrm{a})(2)$.

76 See Dothard v Rawlinson, 433 US 321, 334 (1977) ("We are persuaded-by the restrictive language of $\$ 703(\mathrm{e})$, the relevant legislative history, and the consistent interpretation of the Equal Employment Opportunity Commission-that the bfoq exception was in fact meant to be an extremely narrow exception to the general prohibition of discrimination on the basis of sex.") (internal citations omitted). See also Diaz v Pan American World Airways, Inc, 442 F2d 385, 389 (5th Cir 1971) (stating that the EEOC's rejection of customer preference in the BFOQ provision is entitled to "great deference"). 
These rules have two virtues. First, they are consistent with Johnson Controls, in that they narrow the application of the privacy BFOQ. They do so by helping courts determine whether the essence of the defendant's business actually includes privacy. Second, they pay due deference to the EEOC guidelines because they do not perpetuate sex stereotypes. This proposal will limit the availability of the privacy $B F O Q$ and, in doing so, will strain existing norms of privacy and conceptions of appropriate gender roles. Such a shift might have costs, given that a violation of a person's deeply-felt privacy interest might cause real pain. But there will be a benefit as well-less sex discrimination. Thus, before explaining the proposal in greater detail, this Part presents historical evidence to support the notion that privacy interests and conceptions of appropriate gender roles can change and have changed, despite the costs.

\section{A. The Desexualization of the Medical Profession}

If there is such a strong privacy interest in having a female nurse in the delivery room, why do so many patients accept a male obstetrician delivering the baby? The obvious answer is that women do not think of obstetricians in the same way. But this was not always the case. An examination of the history of obstetrics in America reveals how mutable feelings of privacy can be. Despite a long period of history where the sexual connotations of childbirth presented considerable barriers to male doctors assisting in childbirth, by the midnineteenth century a coalition of physicians and lawmakers were successful in persuading women to accept what they at first believed to be deeply-felt violations of their privacy. ${ }^{n}$ This coalition was so successful that today the "social organization of modern obstetrical care denies or hides the sexual implications of childbirth, and thus minimizes or eliminates role conflict for the male physician." ${ }^{78}$ However, before male obstetricians could replace the female midwife, "men had to be defined as socially acceptable persons to attend childbirth.",

For centuries women attended to other women during the birthing process because women could not accept men witnessing this intimate female event. ${ }^{\text {so }}$ This embarrassment extended beyond women

77 Dara Clapper Brack, Displaced-The Midwife by the Male Physician, in Ruth Hubbard, Mary Sue Henifin, and Barbara Fried, eds, Women Look at Biology Looking at Women 83, 87 (Schenkman 1979).

78 Id at $86-87$.

79 Id at 83.

80 It was this unwillingness to sacrifice modesty that actually helped some women gain entrance into the medical field. Many women's beliefs that "the room of confinement is properly woman's place" facilitated the entrance of female obstetricians. Judith Walzer Leavitt, Brought to Bed: Childbearing in America 1750-1950 111 (Oxford 1986). "[W] hen women physicians began to be available, their services were sought by women from all economic and cultural back- 
to professors and students of obstetrics. Students generally received only a theoretical education about the women they would be treating and did not actually observe women in labor during their schooling. ${ }^{\text {s. }}$

Samuel D. Gross, a student who observed Thomas Chalkley James teaching obstetrics at the University of Pennsylvania early in the nineteenth century, noticed that "it was seldom that he raised his eyes from his manuscript, or looked squarely at his audience. His cheeks would be mantled with blushes while engaging in demonstrating some pelvic viscus .... It was often painful to witness his embarrassment.",

William Potts Dewees, teacher of obstetrics and author of the influential text, $A$ Compendious System of Midwifery, ${ }^{84}$ remained horrified by the idea of visual inspection of women's genitals. "Using manikins [sic], he taught his students how to perform unsighted digital explorations of parturient women.... [S]tudents learned to examine women's genital tracts without looking at what they were doing.",s5 Dewees urged that the patient's body should not be exposed, and that the attendant should be able to perform without the aid of sight. ${ }^{86}$ An obstetric student at Harvard recounted that practical obstetrics was limited: "A female pelvis was placed on the table. The head of a rag baby was thrust into it. It was our duty to ascertain the presentations, and to deliver with forceps."

While the association between childbirth and sexuality initially presented a barrier to the entrance of male physicians into obstetrics, physicians eventually forced female midwives out of the profession they had once dominated. The probable reason for this is a combination of factors, including doctors' realization that substantial economic gains could be achieved if they eliminated the midwife competitors, as well as the fear that "the obstetrician would never receive due recognition in the 'overcrowded' medical profession as long as women,

\footnotetext{
grounds. Some native-born upper-class women in the middle of the nineteenth century went to extreme lengths to procure the services of women." Id at 113-14.

81 Id at 115. "When male medicine [eventually] entered the birthing rooms of America in the eighteenth and nineteenth centuries, it entered on tiptoe." Id.

82 See id at 40.

83 Id.

84 William Potts Dewees, A Compendious System of Midwifery (Lea \& Blanchard 10th ed 1843).

85 Leavitt, Brought to Bed at 41 (cited in note 80 ).

86 See id.

87 Id at $41-42$

88 See Judy Barrett Litoff, American Midwives: 1860 to the Present 48 (Greenwood 1978) ("Doctors maintained that overcrowding had resulted in a loss of their status and a diminution of their income. Not surprisingly, they began to devise plans for the purpose of limiting the number of medical practitioners.").
} 
untrained in the medical sciences, continued to serve as birth attendants." "

This was not an overnight process, and male physicians had to challenge prevailing norms regarding privacy." The desexualization occurred in part because physicians were able to manipulate the legal system. For example, doctors "call[ed] for the elimination of the midwife on the grounds that she posed an economic threat to the medical profession." "' In response, some states, such as Massachusetts, abolished midwives entirely. ${ }^{\text {s2 }}$ Others implemented programs that required the licensing, regulation, supervision, and examination of the qualifications of midwives in order to control their expansion and their institutionalization." Additionally, several states required that the midwife be a graduate of a "recognized" school, yet there were no statesponsored schools for midwives." Some states even enacted laws preventing midwives from using any drugs, including silver nitrate, which was commonly used to treat babies' eyes to prevent blindness. "[T]he midwife had the choice of breaking the law or leaving the baby's eyes to chance." All of these programs were designed to result in the ultimate elimination of midwives.

By the 1960s, almost 99 percent of American babies were delivered by physicians, more than 93 percent of whom were male. Male physicians had succeeded in desexualizing childbirth, but there were costs to this desexualization. One was lower-quality health care. Male physicians gained access to delivery rooms because women believed that physicians, who brought with them into the practice anesthesia, morphine, and forceps, also brought increased safety. In fact, male doctors used techniques that were much more dangerous than those used by midwives. ${ }^{\text {s. }}$ The safety record of male obstetricians in the nineteenth century, as measured by mortality statistics, "matched or was worse than the record of midwives, who continued to follow a basi-

89 Id at 64.

90 See Brack, Displaced at 87 (cited in note 77).

91 Litoff, American Midwives at 73 (cited in note 88).

92 See id at 79.

93 See id at 79-80. Still other states replaced midwives by establishing maternity dispensaries and hospitals. Dispensaries aided women who delivered children in their own homes, while the hospitals provided care for those who could not secure proper care at home. See id at 73-74.

94 See id at 99.

95 Id at 101.

96 See id at $80-82$.

97 See Brack, Displaced at 83 \& n 2 (cited in note 77).

98 See Frances E. Kobrin, The American Midwife Controversy: A Crisis of Professionalization, in Judith Walzer Leavitt and Ronald L. Numbers, eds, Sickness and Health in America: Readings in the History of Medicine and Public Health 217,218 (Wisconsin 1978). 
cally noninterventionist birth policy"9 and. a medical study reported that in 1912, doctors lost more patients than midwives. ${ }^{100}$

Another cost of desexualizing childbirth was the rise of the first anti-abortion movement in the United States, which was directly linked to the domination of obstetrics by male doctors and resulted in the regulation of female bodies by men. ${ }^{101}$ This anti-abortion movement promoted a hierarchical vision of the relationship between men and women and contributed to the patriarchal culture generally; ${ }^{102}$ it subordinated a woman's ability to control her body to laws that came into being as a result of male physicians. Similar to the costs incurred by women as a result of lower-quality health care, women generally have suffered consequences as a result of their subordination to men. ${ }^{103}$ Society bore these substantial costs so that men could become gynecologists and obstetricians.

In desexualizing the field of obstetrics, both men and women overcame, to a great extent, their embarrassment about intimacy. Men did this because they wanted access to a profession from which they had been excluded. Women did this because they wanted (and mistakenly thought they were getting) better health care. As a result, the cultural perception that it was improper for men to be involved in childbirth was shattered.

It may be true that women would not have been willing to bear the burden of sacrificing their privacy for anything other than the supposed benefits of improved health and safety to themselves and their future children. Women may be less willing today, consciously or unconsciously, to bear a similar burden of privacy infringement for the sole benefit of alleviating sex discrimination in the workplace. The purpose of this historical information, however, is to illustrate that notions of privacy can change, and will if the benefit received is deemed sufficiently worthy.

The next Part sets forth two rules that courts should adopt, in order to narrow the construction of the privacy BFOQ in conformity with Johnson Controls. In light of this historical evidence that privacy norms are adaptable, this proposal is viable.

99 Leavitt, Brought to Bed at 56 (cited in note 80).

100 See id.

101 See Reva Siegel, Reasoning from the Body: A Historical Perspective on Abortion Regulation and Questions of Equal Protection, 44 Stan L Rev 261, 280-319 (1992).

102 See id.

103 Reva Siegel argues that history demonstrates that "claims about women's bodies can in fact express judgments about women's roles. ... Physicians regularly depicted abortion as an act of feminine role resistance, encouraged by feminist advocacy. In so doing, they invested abortion with symbolic meaning, urging Americans to oppose abortion in order to defend gender roles in diverse spheres of social life." Id at 281. 


\section{B. The First Rule:Asymmetric Policies Are Impermissible}

The first rule is that if an employer has an asymmetric sexdiscriminatory policy, then sex is not a BFOQ based on privacy. For example, an employment policy that permits female nurses to provide intimate care for male patients but does not permit male nurses to provide intimate care for female patients is asymmetric and should not be allowed-for how can privacy be at the essence of the business if the privacy interests of male patients are not being protected? ${ }^{104} \mathrm{Al}-$ though asymmetric policies are often justified as an attempt to protect patients' privacy rights, generally these policies cater to stereotypes about the appropriate roles for men and women. For instance, an asymmetric policy might be grounded in anachronistic ideas about the need for women to be sexually modest, or that nursing is a job for women. Title VII and the EEOC guidelines are intended to combat discriminatory policies based on sex stereotypes. ${ }^{105}$ There is no reason that employment policies should be asymmetrical given the fact that, as historical evidence supports, norms surrounding privacy and "proper" gender roles can change if there is a greater good to be achieved.

This stereotyping is reflected in the major cases that have allowed privacy BFOQs in the health care industry. ${ }^{106}$ For instance, the nursing home in Fesel implemented its asymmetric policy because it believed that women were concerned about exposing their naked bodies to men, while men were not concerned about exposing their naked bodies to women. The nursing home made generalized arguments based on the attitudes of a few women. The home did not make the same generalization about male patients, although one or two male patients must have preferred treatment by men. The Fesel court acknowledged that the female-only policy perpetuated stereotypes: "[T]he attitudes of the nonconsenting female guests at the Home are undoubtedly at-

104 Note that I do not intend for this argument to apply in situations where privacy in conjunction with another factor, such as rehabilitation or fear of violence, may establish a BFOQ. For example, I am not arguing that women's rape shelters should not be permitted to invoke the BFOQ exception in order to hire female therapists to aid female victims of rape. In this situation, there may be privacy interests at stake, but more importantly, there are issues of safety and rehabilitation which may justify a same-sex BFOQ.

105 See Sprogis v United Air Lines, Inc, 444 F2d 1194, 1198 (7th Cir 1971) (stating that Section 703(a)(1) of Title VII was "intended to strike at the entire spectrum of disparate treatment of men and women resulting from sex stereotypes"); Ridinger v General Motors Corp, 325 F Supp 1089, 1096 (S D Ohio 1971) (stating that in enacting the Title VII prohibition against discrimination on account of sex, Congress intended to prevent employers from refusing to hire an individual based on stereotyped characterizations of his or her sex), revd on other grounds, 474 F2d 949 (6th Cir 1972). See also EEOC Dec No 77-36, 1977 WL 5351, *3-4 (1977) (citing Sprogis for the proposition that Congress intended Title VII to strike at disparate treatment of men and women resulting from sex stereotypes).

106 See Part I.A. 
tributable to their upbringing and to sexual stereotyping of the past."107 By its own words, the Fesel court disregarded the EEOC's clear statement that the BFOQ defense does not apply where it is based on "stereotyped characterizations of the sexes."

Asymmetric policies also perpetuate the stereotype that nursing is a woman's job. For the past century nursing has been dominated by women, who are portrayed in society as nurturers and care-givers. Male entry into the nursing profession during the twentieth century has been slow. In fact, in 1996 men represented only 5.4 percent of total employed nurses. ${ }^{110}$ During wartime, women provided medical care to injured soldiers since there were very few men available to perform these services. Men, by necessity, were forced to receive intimate care by women. Women are not accustomed to receiving male nursing care because, as the statistics show, they generally have not received this care. Nurses' jobs are generally thought to be "women's jobs" rather than "men's jobs." The EEOC specifically stated that the BFOQ should be limited in these situations: "The commission believes that the bona fide occupational qualification exception as to sex should be interpreted narrowly. Label[s] - 'Men's jobs' and 'Women's jobs'tend to deny employment opportunities unnecessarily to one sex or the other."

In fact, a recent study provides support for the argument that people's notions of privacy are based on stereotyped characterizations of the sexes. ${ }^{12}$ This study was conducted in order to identify if there was any relationship between the intimacy of a nursing interaction and the patient's level of embarrassment. The study consisted of completed questionnaires from ninety-eight gynecological patients who received-intimate care from nurses. It found that in a population of patients who have no prior experience of hospital admission, or of being cared for by a male nurse, there is a preference for care by a female nurse. However, this preference is not demonstrated in patients who

107 Fesel, 447 F Supp at 1352.

10829 CFR § 1604.2(a)(1)(ii).

109 See Henry Etzkowitz, The Male Sister: Sexual Separation of Labor in Society, 33 J Marriage \& Fam 431, 432 (1971) ("The role of nurse has been accepted as being especially congruent with the traditional role of the female in western culture."); Christine Neylon O'Brien and Margo E.K. Reder, Comment, Modeling an Employment Policy to Unify Workers' Rights with Fetal Protection, 24 Ariz St L J 1149, 1176 n 143 (1992) (referring to nursing as a "traditionally female occupation").

110 See Survey of RNs Shows Strong Opportunities in Nursing, 30 The American Nurse 1 (Jan/Feb 1998), available online at <http://www.nursingworld.org/tan/98janfeb/survey.htm> (visited Apr 17,2000).

11129 CFR $\$ 1604.2$ (a) (emphasis added).

112 See Nicholas N. Lodge, et al, A Study to Ascertain Gynecological Patients' Perceived Levels of Embarrassment with Physical and Psychological Care Given by Female and Male Nurses, 25 J Advanced Nursing 893 (1997). 
have undergone previous hospital admission within the last five years or who have been cared for by a male nurse.

The authors concluded from their findings that the cultural preference among gynecological patients for care by a female nurse is changed by experience during hospital admission. ${ }^{113}$ This study supports the argument that women generally prefer female rather than male nurses, at least in part, because they have only been treated by female nurses. In the views of these inexperienced patients, nurses should be women. However, once they have received treatment by male nurses, their stereotypes are shattered, and their preferences begin to shift.

In addition to being grounded in stereotypes, asymmetric policies undermine the logic of employers' and courts' argument that privacy interests can be protected only by hiring employees who are the same sex as the customers. For example, the residential retirement home in Fesel refused to hire male nursing aides because their duties included such things as bathing patients and inserting catheters. Male aides who performed these duties allegedly would violate privacy rights of female residents. ${ }^{114}$ However, female aides must have attended to male patients at the retirement home because more than 20 percent of the residents were male, and all aides were female. ${ }^{115}$ The court did not comment on this inconsistency and evidently was not troubled by the asymmetric nature of the privacy BFOQ.

\section{The Second Rule: If Male Doctors Can Treat Female Patients, Then Male Nurses and Aides Can as Well}

Courts should adopt a rule that an employer who has a sexdiscriminatory policy with respect to nurses or nursing aides but not doctors may not successfully assert a privacy BFOQ. The duties of nurses, aides, and doctors generally require a similar level of intimacy; thus, there is little justification for treating them differently with respect to jobs that involve intimate duties." ${ }^{1.6}$ The courts that have permitted the privacy BFOQ in the health care context failed to acknowledge that male doctors treat female patients in an intimate manner every day. For example, in Backus, the court took little notice of the fact that only two of the eleven obstetricians at the defendant's

113 See id.

114 See Fesel, 447 F Supp at 1353.

115 See id at 1348 .

116 Some might disagree with this statement; it is difficult to quantify the level of intimacy involved in various jobs, particularly given the subjective nature of the inquiry. All of these occupations clearly require some level of intimacy, and while it is possible for there to be slight variation among occupations, there is also variation within occupations. Regardless, small differences in the level of intimacy should not dictate differential employment policies. 
hospital were female. ${ }^{117}$ This fact undercuts the argument that patients' privacy interests are violated by opposite-sex treatment.

Obstetricians, nurses, and nurses' aides have a similar degree of intimacy with patients. A physician's examination of a vagina is no less intimate than a nurse's. ${ }^{118}$ In fact, it should be more thorough. The same is true with a nurse and doctor who are preparing a male patient for a penile implant. Both doctors and nurses are trained to be gentle in their examination, and empathic and understanding toward the patient. ${ }^{119}$ Nurses' aides, similarly, must be gentle yet professional when bathing patients. When gathering a patient's history, doctors and nurses alike are taught to ask about such personal matters as sexual history, pregnancy history, eating disorders, domestic abuse, and drug addictions. ${ }^{200}$ One manual instructs physicians that the purpose of the initial interview is "to establish a trusting and supportive relationship with the patient, and to offer information and counselling.... Providing emotional support not only enhances the gathering of information but in itself is part of the therapeutic process of patient care. ${ }^{121}$

Furthermore, the health care setting can be structured so as to minimize intimacy associated with the job. For example, the desexualization of fields like obstetrics ${ }^{12}$ has been attributed to several factors, including " $[t]$ he removal of the woman from a familiar environment; the emotional neutrality of the doctor-patient relationship; the rituals of aseptic technique and surgical preparation; the routine use of medication and forceps; and finally, the routine use of anesthesia." ${ }^{123} \mathrm{Sev}-$ eral of these factors, particularly the first two, apply to nurses and aides as well as doctors. Concerned employers can follow similar steps to desexualize the duties of any of their employees. In fact, courts may require employers to take these steps to minimize intimacy as a reasonable accommodation. The second prong of the essence of the business test requires courts to determine that no reasonable accommodation can be made before allowing a privacy $\mathrm{BFOQ}$, and the above procedures are likely to be considered reasonable.

Of course, there are differences among the jobs of physicians, nurses, and aides-some of which are real and some of which are perceived. Real differences include level of education and income. Another difference is that physicians generally are capable of performing

117 See Backus, 510 F Supp at 1192.

118- See Lynn S. Bickley and Robert A. Hoekelman, Bates' Guide to Physical Examination and History Taking 410-17 (Lippincott 7th ed 1999); Yondell Masten, The Obstetric Survival Handbook 52-53 (Skidmore-Roth 1998).

119 See Bickley and Hoekelman, Bates' Guide at 410-11 (cited in note 118).

120 See id at 1-13; Masten, The Obstetric Survival Handbook at 21-47 (cited in note 118).

121 Bickley and Hoekelman, Bates' Guide at 1 (cited in note 118).

122 See Part II.A.

123 Brack, Displaced at 87 (cited in note 77). 
duties that the others are not, such as performing surgery or prescribing medication. Perceived differences, which may or may not be true, largely stem from the real differences, and could include the following: (1) nurses are less professional than doctors; (2) aides are more likely than doctors to abuse patients' trust; (3) patients become closer, emotionally, with their nurses than their doctors.

The notion that nurses infringe more on patients' privacy than doctors seems to be motivated by the perceived differences between the occupations rather than real ones. A claim of differential intrusion cannot be due to real differences. A male nurse with two years of posthigh-school education and an annual income of $\$ 30,000$ poses no greater privacy intrusion upon a woman to whose genitalia he is exposed during the course of work than a male doctor with eight years of post-high-school education and a $\$ 200,000$ annual income-income is irrelevant to the level of intrusion. Also, physicians' ability to perform duties such as surgery or gynecological examinations would make doctors intrude more, not less, on privacy, than nurses.

The perceived differences, upon which the claim of different levels of intrusion rests, do not exist. First, there is no reason to presume that nurses will perform their duties in a less professional manner than doctors. Both have special training and expertise within the scope of their duties, and both are subject to discipline for failure to perform duties in an appropriate manner. Second, there is no reason to think that nurses will be more likely to abuse their patients' trust than doctors. If nurses are able to establish a greater degree of trust with patients than doctors, they may be better able to abuse that trust. But the greater authority of doctors would actually allow physicians to more easily take advantage of patients. In any case, there is little reason to assume that nurses are more inclined to abuse patients' trust than doctors.

Finally, there is no reason to think patients will become emotionally closer to their nurses than their physicians, unless, perhaps, the more frequent interaction with the nurse builds a relationship of trust with the nurse. If this is true, however, the examinations by the trusted nurse rather than the less familiar doctor should be less intrusive on privacy due to the trust that has developed between patient and nurse.

\section{Potential Costs Related to the Second Rule}

1. Sexual abuse.

One might argue that same-sex treatment is necessary to prevent sexual abuse of patients, but this argument is questionable as long as male physicians are permitted to intimately treat female patients. The incidence of sexual abuse by male physicians of female patients is sub- 
stantial. ${ }^{124}$ This type of abuse has increased from 2.5 percent of all offenses committed by doctors to 5 percent of all offenses between 1990 and 1995 . $^{125}$ In fact, a recent study reported that four of ten doctors disciplined for sex offenses nationwide still practice medicine. ${ }^{126} \mathrm{De}-$ spite the evidence of abuse, men are not denied the opportunity to practice as obstetricians or gynecologists.

Nor should men be denied jobs as nurses and aides, particularly where employers can make reasonable accommodations to protect against patient abuse. Employers who are concerned about the possibility of sexual abuse of patients by nurses or aides can implement chaperone policies, as some health facilities currently do for physicians, suggesting that these accommodations are reasonable. Also, employers can require sexual awareness classes for nurses and aides. The classes might emphasize that sexual (and non-sexual) abuse is not tolerated, and can suggest appropriate methods of performing intimate tasks to avoid impropriety. Such classes can also inform employees of the repercussions of committing abuse, which include termination and criminal prosecution.

2. Extending the privacy BFOQ to physicians.

Employers could attempt to satisfy the second rule by extending the privacy BFOQ to physicians. ${ }^{127}$ This would eliminate the asymmetry because doctors and nurses alike could not provide medical care for members of the opposite sex. However, extending the privacy BFOQ to physicians has troubling implications. As Part II.A illus-

124 The results of a medical study performed in Britain indicated that 8 percent of the women sampled reported experiences where doctors had conducted a gynecological examination in a "Iess than professional manner." This involved overexposure of the woman's body, inappropriate comments and gestures, and being examined in an unusual position. The same study also concluded that, of the lead physicians in genitourinary medicine clinics that were surveyed, 8 percent were aware of allegations of unprofessional behavior in their departments in the preceding five years. C.J. Bignell, Chaperones for Genital Examination, 319 BMJ No 7203 137, 13738 (July 17, 1999). See also Deal Swifter, Stronger Punishment to Doctors Who Betray Trusted Role, Ft Lauderdale Sun-Sentinel 10A (July 7, 1997) (stating that a report issued by Ralph Nader's Public Citizen organization documents the cases of 542 doctors who were disciplined for molestation of their patients).

125 See Leslie Nicholson, Research Reports, 13 Med Malpractice L \& Strategy No 8, 6 (June 1996).

126 This statistic was determined by a nationwide study conducted by Public Citizen in Washington D.C. See Christine E. Dehlendorf and Sidney M. Wolfe, Physicians Disciplined for Sex-Related Offenses (Public Citizen Health Research Group 1997). See also Deal Swifter, Stronger Punishment, Ft Lauderdale Sun-Sentinel at 10A (cited in note 124).

127 See Michael R. Lowe, Stirring Muddled Waters: Are Physicians with Hospital Medical Staff Privileges Considered to Be Employees Under Title VII or the Americans with Disabilities Act When Alleging an Employment Discrimination Claim, 13 Labor Law 225, 226-27 (1997) (noting that hospitals have broad latitude to condition physicians' privileges and, in some cases may not even be constrained by Title VII or the Americans with Disabilities Act). 
trates, the medical profession has made great strides in desexualizing the profession, especially in the fields of obstetrics and gynecology. It was not until this desexualization began to occur that women first agreed to receive intimate treatment by male doctors. Extending the privacy BFOQ to male obstetricians and gynecologists would have the perverse effect of resexualizing the profession. Additionally, endorsing such an exception to Title VII would send a message that opposite-sex treatment is inappropriate, and would perpetuate the sex stereotypes that the EEOC guideline prohibits.

Extending the privacy $\mathrm{BFOQ}$ to doctors is also troubling because it would hinder the employment opportunities of thousands of trained physicians and might ultimately lead to the demise of the male obstetrician and gynecologist. ${ }^{128}$ Given this country's commitment to equal employment, the privacy BFOQ should not be extended to physicians absent a compelling justification.

\section{Women's choice of doctor.}

Health care providers may wish to hire only female gynecologists and obstetricians, because demand for female doctors may exceed supply. A woman's ability to choose the sex of her doctor may be limited if health care providers are not allowed to hire only female gynecologists and obstetricians. Asymmetric employment policies would therefore be justified as a way to compensate for the scarcity of female doctors. Two points can be said about this. First, a narrow construction of the privacy BFOQ will have little net effect on patients' abilities to choose the sex of their doctors. Patients in the managed care system are currently limited in their ability to choose their doctors' sex. Many managed care organizations provide patients with a list from which they must choose their physicians, but physicians on the list are often unavailable to take on new patients, leaving patients with little choice as to who will become their doctor.

Second, patients should not be granted an inviolable right to choose doctors on the basis of sex, since sex says little about a doctor's

128 See note 16, discussing the increasing preference by females for female obstetricians and gynecologists, and the increasing supply of female obstetricians and gynecologists.

129 See Mindelle Jacobs, Female Docs in High Demand, Edmonton Sun 35 (July 29, 1999). Jacobs describes how in Canada women are finding it difficult to see female doctors because less than 20 percent of female doctors are accepting new patients. As a result, it takes women months to find a female physician, and many end up seeing a male physician. Id. Anecdotal evidence supports the conclusion that the same is true for women who seek to be treated by female physicians in the United States. In support of the proposition that patients increasingly have less choice over their doctors, see Andy Miller, HMO Satisfaction Declines in Survey, Atlanta J \& Const D3 (Oct 20,1999) (stating that the biggest reason why patients in traditional health plans are more satisfied with their health plan than those in HMOs is because of the ability of patients in traditional plans to choose their doctor). 
qualifications ${ }^{130}$ and selecting a doctor because of her sex perpetuates privacy norms and invidious discrimination. Also, as Part II.E describes, to the extent that a doctor's sex is extremely important to some patients, the market will respond to that demand in such a way that the rules set forth above will be inapplicable, and thus will not prevent a successful privacy BFOQ.

\section{E. The Market's Response to Changes in Demand}

This proposal, if applied by courts, will narrow the use of the privacy $B F O Q$. But courts will not be able to apply these two rules in every instance where an employer asserts a privacy BFOQ. Imagine, for instance, fifteen female physicians who decide to go into private practice together and agree to open a women's health care facility ("Facility"). The Facility treats only women, and all of the participating physicians are female. Suppose then, that David responds to an advertisement for a physician's assistant position at the Facility. He attempts to fill out an application but is told that only women are considered for the position. In fact, every person on staff at the Facility is female, and every patient is female.

David brings a Title VII claim against the Facility, alleging that he was the victim of intentional discrimination because of his sex. The Facility raises an affirmative defense. They assert that female sex is a BFOQ for all positions at the Facility in order to protect the privacy interests of the patients. A court presiding over this case could not apply either of the rules set forth above. The first rule does not apply because there are no male patients, so there can be no female physician's assistants treating patients of the opposite sex. The second rule is not applicable either, because there are no male physicians treating female patients. Thus, the rules in Parts II.B and II.C serve no use in this instance.

This scenario illustrates that if courts adopt this proposal and limit the use of the privacy BFOQ, there is still room for the market to compensate for customer preferences. If there is a demand by women, for example, for all-female medical treatment, the market will adjust to provide this option, and it will not be prohibited from doing so by either rule. Allowing a BFOQ at the Facility maintains the status quo instead of challenging notions of privacy and permits the perpetuation of sex stereotypes. But the rules set forth in this Comment do not address this situation: they limit the application of the BFOQ only to those situations where the rules can be applied-where there are male

130 While there is anecdotal evidence indicating that female OB-GYNs spend more time with their patients than male OB-GYNs, there is no conclusive evidence that the female OBGYNs provide better-quality health care than male OB-GYNs. 
and female patients, and where there are physicians treating patients of the opposite sex.

\section{CONCLUSION}

This Comment argues that a recent Supreme Court case, International Union, UAW v Johnson Controls, Inc, requires courts that are called upon to determine whether sex is a BFOQ based on privacy to alter their analyses. Johnson Controls calls for a more restrictive interpretation of the BFOQ and emphasizes the importance of ensuring equal employment opportunities. Sex cannot be a BFOQ unless it is necessary to the essence of the business. This is true even where an occupation demands exposure to intimate body parts. Given that more and more doctors are becoming salaried employees subject to Title VII, and given that there is an increasing preference among women to be treated by female obstetricians and gynecologists, it is important that courts properly take a narrow approach to the "essence of the business" test, as required by Johnson Controls. If they do not, obstetrics and gynecology might be re-sexualized, and many trained physicians may have a difficult time obtaining salaried positions.

This Comment proposes two rules which must be satisfied in order for a health care provider to demonstrate successfully that sex is a privacy BFOQ. First, courts should not permit a privacy BFOQ where nurses of one sex (for example, female) are allowed to treat patients of the opposite sex (male) but nurses of the other sex (male) are not allowed to treat patients of the opposite sex (female). Second, a BFOQ for nurses or aides should not be permitted if the employer permits physicians to engage in intimate opposite-sex treatment of patients. If either of these conditions is not satisfied, sex is not a privacy BFOQ because presumptively, the essence of the particular business does not include the protection of patients' privacy interests. 


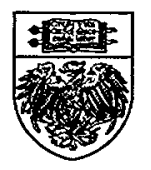

